\title{
Effects of Internal Audit Function on Financial Performance in Rift Valley Bottlers Limited Eldoret, Kenya
}

\author{
Article History \\ Received: 22 December, 2020 \\ Revised: 28 January, 2021 \\ Accepted: 04 February, 2021 \\ Published: 09 February, 2021 \\ Copyright () 2021 Noble Academic \\ Publisher \& Author
}

\author{
Dr. Gedion A, Omwono* \\ Department Of Business Management \& Economics, UoK
}

John mark Wanyama

MBA (Finance) The Catholic University of Eastern Africa, Gaba Campus

Eldoret

\begin{abstract}
The purpose of this study was to investigate effect of internal audit function on financial performance of Rift Valley Bottler's Limited, Eldoret. The researcher seeks to answer the following research questions: what is the effect of internal audit function on financial performance at Rift valley bottlers?; what is the effect of risk management on financial performance of Rift valley bottler's limited Company?; what is the effect of budgetary controls on financial performance of Rift Valley bottler's limited company?; and what is the effect of financial accountability on financial performance of Rift Valley bottler's limited company? This study adopted descriptive cross-sectional research design. With a sample size of 40 from finance, human Resource and procurement departments. Census sampling technique was used to select respondents. Questionnaire was used as data collection instrument. Quantitative analysis was used in analyzing of data. Multiple regression analysis was used to show the relationship between independent and dependent variables. This study found out that budgetary control affects financial performance of Rift Valley bottler's limited company $(\mathrm{p}=0.004)$. this study further asserted that financial accountability affects financial performance of Rift Valley bottler's Limited Company $(p=0.005)$. This study concludes internal audit function affects financial performance of Rift Valley Bottler's Limited company. This study recommends organizations like Rift Valley Bottlers to always practice internal auditing of their creditors and this will improve on their financial performance; organizations should always conceive and adhere to the internal audit function in a positive way as it is communicated by employees and follow their contents in the day to day running of the organization activities; and training of employees in Rift Valley Bottlers as important motivational tool for motivating employees towards better performance.
\end{abstract}

Keywords: Internal audit function financial performance Rift Valley Bottlers.

\section{Introduction}

\subsection{Background to the Problem}

The purpose of the Institute of Internal Auditors is described by one of its founders, Robert B. Milne in 1945 (Flesher, 1996). The Institute is the outgrowth of the belief on the part of internal auditors that an organization was needed in the structure of American business to develop the true professional status of internal auditing. Although its roots are in accountancy, its key purpose lies in the area of management control.

This initial purpose of the Institute of Internal Auditors was more visionary than reality. In practice, internal audit was still an accounting related function with a strong link to the external financial auditors. The next steps in the professionalization of internal audit were the Statements of Responsibilities of the Internal Auditor (Gupta and Ray, 1992; Sawyer and Dittenhofer, 1996). The purpose of these statements was to provide a general understanding of the need for a global professional institute as it became evident after chapters of the Institute of internal Audit spread from the United States to other countries.

Although internal audit is not included in the Sarbanes-Oxley act, the law turned out to have great consequences for internal audit functions. The U.S. legislator took the setting of audit standards for the audits of public firms away from the AICPA, a private standard setter, and created a new body, the Public Company Accounting Oversight Board (PCAOB), to set the audit standards for public firms (Rittenberg and Covaleski, 2005).The directions in the Audit Standard are based on the internal control framework established by COSO and caused this to be more widely known and applied. The Sarbanes-Oxley act also has some limitations. The approach stresses on financial reporting. 
Another study done in Kenya by Bett (2014) on the relationship between effectiveness of internal audit function and financial performance of companies listed on NSE. The study concluded that effective internal audit function has a positive influence on financial performance of companies listed at the NSE. The study recommended that companies should employ skilled and competent professional internal auditors to strengthen the internal controls and minimize on fraud. With efficient internal controls, cases of fraud, embezzlement and cash mismanagement will be controlled hence supplementing on the level of profits in the company. This study did not empirically show to what extend can the internal audit function minimize fraud and improve the profits of the companies quoted on NSE securities. Therefore, this study sought to investigate the effect of internal audit functions on financial performance of Rift Valley Bottlers Limited, Eldoret, Kenya.

\subsection{Statement of the Problem}

Ideally Internal audit function as part of the company internal control system, the internal audit assesses the efficiency, effectiveness, economy, and fairness of the realization of tasks, provides consulting services to the Company's Management, and promotes the effectiveness of risk management with the aim of creating added value and enhancing business growth.

Currently, Rift Valley Bottler's Limited has been facing challenges which has affected its financial performance in terms decrease in profits percentages $49 \%$ in 2015, 43.1\% in 2016 and $39.7 \%$ in 2017.It can be proved by the current retrenchment process of Staff which is going on due to the current economic conditions, Mergers with other Strong investment Companies like Centum Investment in order to strengthen their financial stability, the Company also is not expanding as required of any business enterprises and therefore this may be as a result of lack of good governance practices.

Studies that have been undertaken on how internal audit functions affects financial performance in other sectors such as: Ondieki (2013) focused on effect of internal audit on financial performance of commercial banks in Kenya where he found out that internal audit standards, independence of internal audit, professional competency and internal control had a positive relationship with financial performance of commercial banks.

Kiema (2015) studied influence of internal audit independence on the financial performance of small and medium enterprises in construction industry in Mombasa County, Kenya where he found out that some construction companies (59\%) within Mombasa County did not accord the internal auditors the independence they deserved to effectively give their opinion on the financial statements of the organizations.

Muhunyo and Jagongo (2018) assessed effect of internal control systems on financial performance of public institutions of higher learning in Nairobi City County, Kenya where they revealed that control environment, risk assessment, control activities and information and communication as indicators of internal control systems have a significant influence on the financial performance of the institutions of higher learning in Nairobi City County, Kenya.

From the above studies undertaken no studies have been done on the effects of internal audit function on financial performance in manufacturing companies. The above studies have majorly focused on control environment, internal audit standards, independence of internal audit and professional competency as internal audit functions but they have not focused on how risk management; budgetary controls; and financial accountability affects financial performance. It was against this background that the study was undertaken to fill the knowledge gap by examining effect of internal audit function on financial performance of Rift Valley Bottler's Limited Company, Eldoret.

\subsection{Research Questions}

The study was guided by the following research question:

i. What is the effect of internal audit functions on financial performance at Rift valley bottlers?

ii. What is the effect of risk management on financial performance of Rift valley bottler's limited Company?

iii. What is the effect of budgetary controls on financial performance of Rift Valley bottler's limited company?

iv. What is the effect of financial accountability on financial performance of Rift Valley bottler's limited company? 


\subsection{Research Hypothesis}

$\mathbf{H}_{01}$ : Internal audit function does not have a significant effect on financial performance of Rift valley bottlers limited Eldoret.

$\mathbf{H}_{\mathbf{0 2}}$ : Risk management does not have a significant effect on financial performance of Rift valley bottlers limited Eldoret.

$\mathbf{H}_{\mathbf{0 3}}$ : There is no significant relationship between budgetary control on financial performance of Rift valley bottlers limited Eldoret.

$\mathbf{H}_{04}$ : Financial accountability does not have a significant effect on financial performance of Rift valley bottlers limited Eldoret.

\subsection{Theoretical Framework}

Agency theory and the internal audit were propounded by Adams (1994) is one of the theoretical frameworks that guided this study. Agency theory is widely used in the accounting literature to explain and predict the appointment and performance of external auditors and financial consultants.

Adams said that, agency theory gives a useful theoretical framework for the study of internal auditing function. The agency theory proposes and predicts the existence of internal audit also helps to explain the role and responsibilities assigned to internal auditors by the organization and that agency theory explains how the internal audit function might be affected by organizational change. This theory is related to this study and helps to explain the role and responsibilities of internal auditors which if used will help to improve financial performance in many organizations in Kenya.

\subsection{Conceptual Framework}

Financial performance of an organization is considered to be an outcome of internal audit functions, risk management, budgetary control and financial accountability. These factors can cause both positive and negative environments for financial performance in terms of budgeting performance and financial Accountability.

\section{Figure 1. Conceptual Framework}

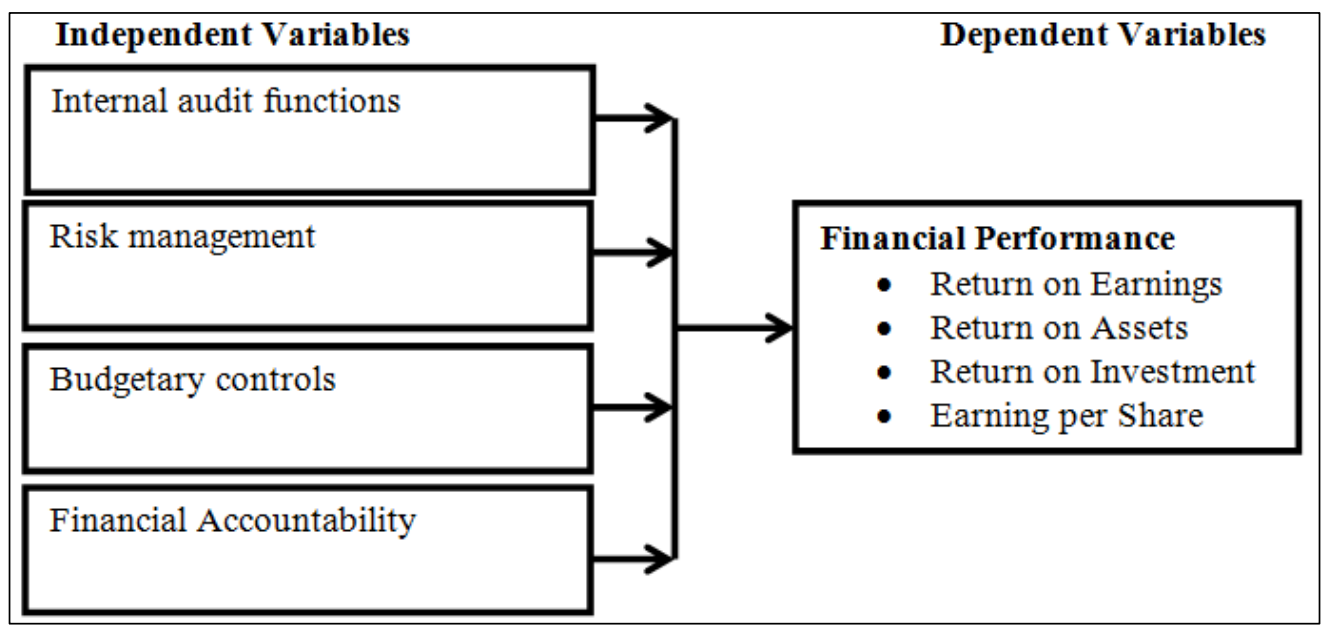

Source: Researcher (2018)

\section{Literature Review}

\subsection{Review of Theories}

\subsubsection{Contingency Theory}

Daft (2012) stated that contingency means, one thing depends on other things. Audit functions are task-oriented and can be loosely structured. The functions also can vary depending on the company undergoing audit and the type of business being undertaken. The auditors should carefully inspect and ensure that the work is well done. The contingency theory can be applied to an audit team's structure. Audit managers usually receive audited projects. They create audit teams for the projects, s appointing auditors based on skills and experience in their specific areas of jurisdiction and also basing on auditor's availability for the work to be done.

The purpose of auditing projects includes evaluation of production processes, inspection of company accounts, and assessing compliance with accounting standards. Quality and output of audits 
remain assured when audit teams use resources according to skills and training they have. An auditor who is experienced in auditing financial statements is usually effective in his work.

\subsubsection{Lending Credibility Theory}

According to Volosin (2007), he mentioned that the lending credibility theory is similar to the agency-theory and it states that audited financial statements can enhance stakeholders faith in management's stewardship. The business world consists of different class of people who are involved in the financial reporting requirements by regulatory bodies. They mainly include shareholders, managers, creditors, employees, government and other groups. The recipients of annual reports are the shareholders, individuals with small shareholding and also institutions such as banks and insurance companies.

\subsubsection{Criticism of Contingency Theory}

The contingency theory of leadership and management states that there is no standard method by which organizations can be led, controlled and managed. Organizations and their functions depend on various external and internal factors. The functions of audits are themselves, types of organizations that are affected by various factors in the environment. The presence of such factors is why auditing can be managed by applying the contingency theory, with a recognition that processes and outcomes of audits are dependent on variable and contingent factors. On a broad level, the audit process is straightforward. Auditors require access to documents, systems, policies and procedures to manage an audit.

Daft (2012) stated that contingency means, one thing depends on other things. Audit functions are task-oriented and can be loosely structured. The functions also can vary considerably, depending on the area of a company under audit and the type of business model, so auditors must carefully manage their inspections and take variables into account to get the job done. The contingency theory also can be applied to an audit team's structure. Typically, audit team managers receive audit projects. They then create audit teams for the projects, selecting auditors based on expertise and experience in the subject areas, and on auditor's availability, all of which add up to contingencies for any given audit. Audit teams use a mix of structure and contingency to get the output rolling quickly. This theory has been criticized because it depends on the leadership and management structures which can easily be manipulated by individuals for their own self- interest.

\subsubsection{Criticism of Leading and Credibility Theory}

The lending and credibility theory have also been criticized because it is a theory of faith where by the stakeholders rely on the information given to them by the management of which it may be misleading and not correct to reflect the true state of affairs of the organization. Their decision is usually based on the financial reporting and the performance of the company's management, who have a responsibility to act in the interests of investors. The auditor is appointed by the company's shareholders and reports his results to his clients. The aim of the auditor's report is to comment on how accurately the company presents its financial situation and how it is performing.

\subsection{Knowledge Gap}

The previous studies focused on the effectiveness of internal audit or internal audit functions in different settings. The studies focused on the effect of Internal Audit and its relationship with financial performance e.g. Ejoh (2014) did a study on the effect of internal audit function on financial performance in colleges in Nigeria and the findings of the study revealed that there was no significant effect of these functions on financial performance.

Bett (2014) also did a study on the effectiveness of internal Audit functions on operations of Commercial banks in Kenya and the study findings showed that there was a relationship between embracing audit functions and the financial performance although the study did not empirically show to what extend does the Internal Audit function affect financial performance and recommended further research to be done to ascertain the degree of effectiveness.

Ebrahim et al. (2014) did a study on the effect of internal Audit and Firm Performance in Malaysia. The study findings were that few studies had investigated the relationship between internal Audit and Firm Performance although from the study, the effectiveness of the internal Audit function was not proved empirically leaving room for further research to be done.

Douglas et al. (2012) did a study on the effect of internal Audit report type and reporting relationship on internal Audit judgments in USA. The study findings were that the internal Audit report type and reporting relationship affect internal Auditors Judgments increasing the conservatism of certain 
risk assessments where accountability to stakeholders or the Audit committee increases. These studies did not widely investigate empirically to what extent risk management, internal control, governance process, as components of internal audit functions affects financial performance of an organization.

The aim of this study therefore, is to contribute further literature to the body of knowledge through empirical examination of the degree to which internal audit function and their effect on financial performance of organizations such as Rift valley bottlers limited in Eldoret town, North- Rift region (Kenya).

\section{Research Design and Methodology}

\subsection{Research Design}

This study adopted descriptive cross-sectional research design. Cross sectional research design is where the definition of the problem has been done by the researcher and certain issues described by the respondents. Quantitative methods of data collection and analysis were used. The respondents were selected from different departments that included: Human Resource, Finance and Audit department, Procurement department, Sales department and processing department. The study sought to investigate the internal audit function and its effect on financial performance of Rift valley Bottlers Limited.

\subsection{Target Population}

Target Population was 40 respondents mainly being employees of the company. Thus, the population fitted a certain specification, which the researcher studied and the population was homogenous. Therefore, Census method was used with the entire (40) respondents sampled under this study.

\subsection{Description of Research Instrument}

\subsubsection{Questionnaire}

This study used self-administered questionnaires as research instruments. Both open and close ended questions were designed for the respondents who were mainly employees of the company. The questionnaires contained both structured and unstructured questions. The questionnaires were divided into 3 sections, Section A- Demographic information, Section B-Internal audit function, C-Risk Management, D- budget control, E-financial accountability, and F-Indicators of financial performance.

\subsection{Description of the Data collection Procedures}

The researcher administered a questionnaire to each respondent of the target population. The questionnaire was carefully designed and tested. This was done in order to enhance its validity sand accuracy of the data collected. Primary data was basically collected through structured questionnaire which were administered to the respondents within the company.

\subsection{Description of Data Analysis Procedures}

The data collected was analyzed to give meaning to the specific aim of the study. The data collected was analyzed using statistical package for Social Sciences (SPSS Version 20) program. Quantitative analysis was used to analyze the data where it involved descriptive and inferential statistics. Descriptive statistics involved frequency tables, pie charts, graphs and percentages. Inferential statistics will involve multiple regression analysis where it helped to show correlation between independent and dependent variables. The data was tabulated using statistical like percentages, tables and charts.

The regression model is as follows:

$Y=\alpha+\beta_{1} X_{1}+\beta_{2} X_{2}+\beta_{3} X_{3}+\beta_{4} X_{4}+e_{i}$

Where:

$\mathrm{Y}$ is the dependent variable (financial performance)

$\alpha$ being the constant.

$\mathrm{X}_{1}=$ Internal audit functions

$\mathrm{X}_{2}=$ Risk management

$\mathrm{X}_{3}=$ Budgetary control

$\mathrm{X}_{4}=$ Financial accountability

$\mathrm{e}_{\mathrm{i}}=$ Error term 


\section{Discussion}

\subsection{Results}

\subsubsection{Background Information}

Before embarking on the main objectives of the study, it was important to find out the background information of the respondents. This was ascertained by looking at the gender of the respondents, age, and education level of respondents. Background information was important as it lays a basic foundation on which interpretation of the study are based.

\subsubsection{Gender of respondents in the study}

Figure 2. Gender of respondents.

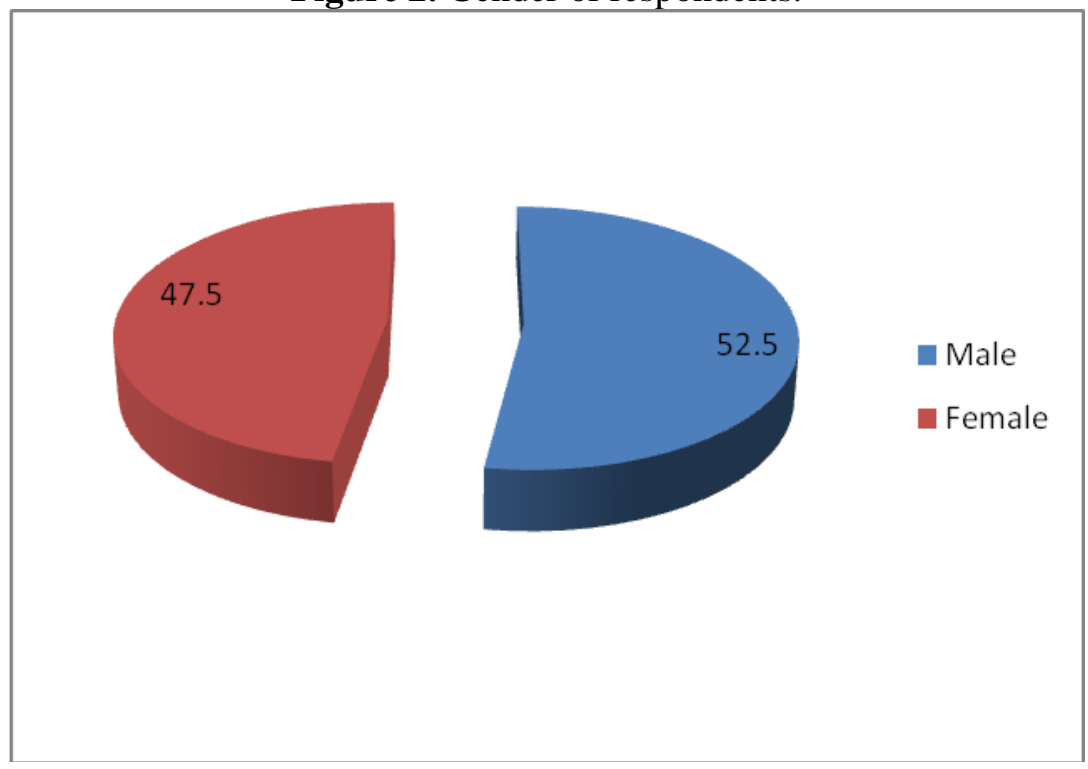

Source: Primary data (2018)

Results show that $21(52.5 \%)$ of the respondents were males while $19(47.5 \%)$ were females. This thus implies that most of the respondents who participated in the study were male.

\subsubsection{Age of Respondents}

The study looked at age of employee and results are summarized in Figure II below;

\section{Figure 3. Age of respondents}

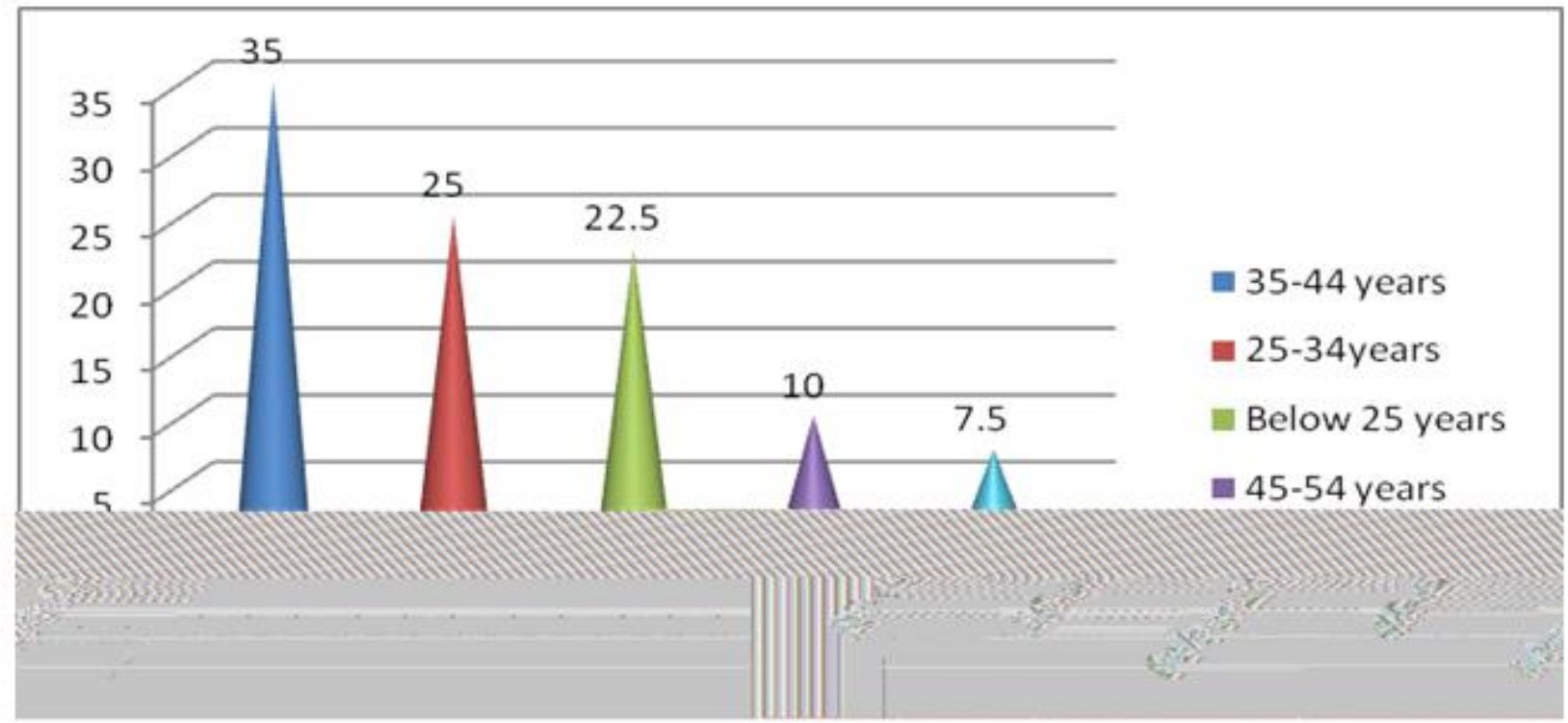

Source: Primary data (2018) 
Findings reveal that $14(35.0 \%)$ of the respondents were between the age of 35-44 years $10(25.0 \%)$ of the respondents were between 25-34 years while 9(22.5\%) were below 25 years. The results further shows that $4(10.0 \%)$ ranged between $45-54$ years while $3(7.5 \%)$ of the respondents were above 54 years. From the results majority of the respondents were between $35-44$ years old.

\subsubsection{Level of Education}

Figure 4 shows the level of education of the respondents.

Figure 4. Level of education

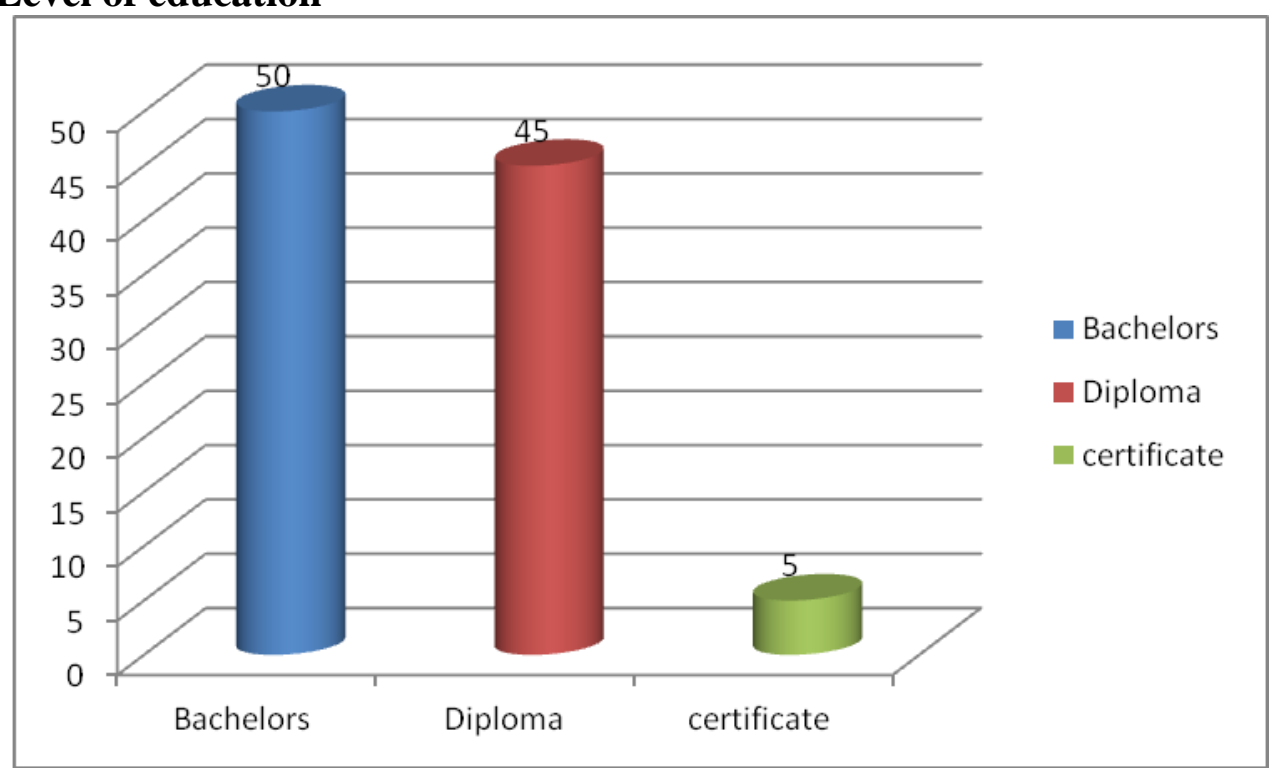

Source: Primary data (2018)

The results indicate that $20(50 \%)$ of the respondents had reached bachelor's level while $18(45 \%)$ had reached diploma level. Certificate level were $2(5 \%)$ of the respondents. These results reveal that majority of the respondents were Bachelor's degree holders.

\subsubsection{Marital Status}

Figure 5 shows the marital status of the respondents as found from the study.

\section{Figure 5. Marital Status}

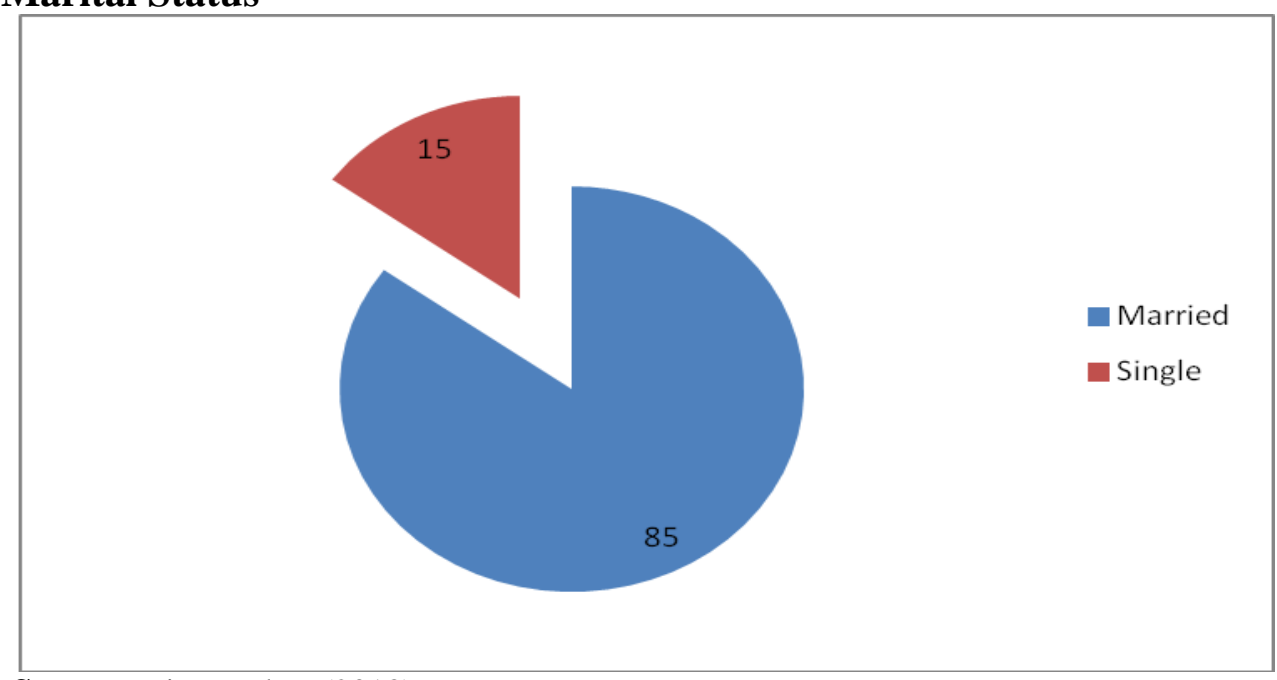

Source: Primary data (2018)

It is observed that $34(85 \%)$ of the respondents were married while $6(15 \%)$ were single. This reveals that majority of the respondents were married. 


\subsubsection{Internal Audit Function}

The study sought to find out the internal audit functions found in the Rift valley Bottlers Limited Company. Results are discussed as follows:

Table 1. Internal Audit Function

\begin{tabular}{|c|c|c|c|c|c|c|c|c|}
\hline & \multicolumn{2}{|c|}{ Strongly Agree } & \multicolumn{2}{|c|}{ Agree } & \multicolumn{2}{|c|}{ Undecided } & \multicolumn{2}{|c|}{$\begin{array}{l}\text { Strongly } \\
\text { Disagree }\end{array}$} \\
\hline & Fre & $\%$ & Fre & $\%$ & Fre & $\%$ & Fre & $\%$ \\
\hline staff adhere to controls & 13 & 32.5 & 22 & 55.0 & 3 & 7.5 & 2 & 5.0 \\
\hline Proper monitoring & 11 & 27.5 & 16 & 40.0 & 13 & 32.5 & 11 & 27.5 \\
\hline Accuracy of information & 11 & 27.7 & 17 & 42.5 & 6 & 15 & 12 & 30.0 \\
\hline record of assets & 11 & 27.5 & 10 & 25.5 & 10 & 25.5 & 19 & 47.5 \\
\hline Assets register & 4 & 10.0 & 18 & 45.5 & 12 & 30.0 & 18 & 45.0 \\
\hline Assets kept in custody & 16 & 40.0 & 19 & 47.5 & 0 & 0 & 5 & 12.5 \\
\hline Company measures & 22 & 55.0 & 14 & 35.0 & 0 & 0 & 4 & 10 \\
\hline Accounts are regularly reconciled & 13 & 32.5 & 18 & 45.0 & 2 & 5.0 & 7 & 17.5 \\
\hline
\end{tabular}

Source: Primary data (2018)

Looking at staff adherence control systems 22(55.0\%) of the respondents agreed, $13(32.5 \%)$ strongly agreed, $3(7.5 \%)$ were undecided while $2(5.0 \%)$ strongly disagreed. From the results it is revealed that the majority $87.5 \%$ agreed that staff adhered to controls in place.

On finding out if there is proper monitoring of internal control systems in the company $16(40.0 \%)$ of the respondents agreed that there was proper monitoring of internal control systems, 11(27.5\%) strongly agreed while $13(32.5 \%)$ were undecided. The results reveal that companies have proper monitoring of internal control systems.

Accuracy of information in any organization is very important in measuring internal control in an organization, the study sought to find out if accuracy of information was emphasized in the company. From table 1 it is seen that 17(42.5\%) of the employees agreed that accuracy of information is emphasized in their company, 11(27.7\%) strongly agreed, 6(15\%) undecided, while 12(30.0\%) strongly disagreed. Table 1 also shows that record of assets is not maintained with 19(47.5\%) of the respondents strongly disagreed, 11(27.5\%) strongly agreeing while 10(25.0\%) agreed, 10(25.5\%) undecided.

Finding also shows that $18(45.0 \%)$ of the employees agreed that assets register is regularly updated $4(10.0 \%)$ strongly agreed $12(30 \%)$ undecided, while $18(45.0 \%)$ strongly disagreed revealing that assets register is regularly updated. The study went further to find out if assets were kept in custody of authorized personnel from table 1 majority of the respondents 19(47.5\%) agreed that assets were kept in custody of authorized personel,16(40.0\%) strongly agreed while only 5(12.5\%) strongly disagreed.

It is also seen that most of the employees $22(55.0 \%)$ strongly agreed that the company has measures to safeguard assets from fire, 14(35.0\%) agreed while 4(10.0\%) strongly disagreed.

On investigating whether Rift Valley Bottlers Limited Company had clear levels of approval and authorization the findings showed that 23(57.5\%) agreed that there were clear levels of approval and authorization and $17(42.5 \%)$ strongly agreed. These therefore imply that there are clear levels of approval and authorization in the company.

Looking at the company identifying risks in terms of sources of risks, it was found from table 2 that majority of employees $21(52.5 \%)$ agreed that company identified risks in terms of sources risk, $11(27.5 \%)$ strongly agreed while 6(15.0\%) strongly disagreed revealing that the Company identifies risks in terms of sources. Results also shows that the company has a risk communication strategy with $18(45.0 \%)$ of the employees agreed, 17(42.5\%) strongly agreed while only 5(12.5\%) were undecided.

On investigating if the company analyzed risks in terms of consequences most of the employees $23(57.5 \%)$ agreed that it analyzed, 11(27.5\%) strongly agreed, 4(10.0\%) strongly disagreed while 2(5.0\%) were undecided implying that coca cola company analyzed risks in terms of consequences.

\subsubsection{Risk Analysis}

Table 2. Risk Analysis

\begin{tabular}{|l|l|l|l|l|l|l|l|l|}
\hline & Strongly agree & \multicolumn{2}{|c|}{ Agree } & \multicolumn{2}{c|}{ Undecided } & \multicolumn{2}{c|}{ Strongly agree } \\
\hline & Freq & \% & Freq & \% & Freq & \% & Freq & $\%$ \\
\hline $\begin{array}{l}\text { Company analyzed its risks in terms of } \\
\text { reputation impact }\end{array}$ & 12 & 30.0 & 12 & 30.0 & 9 & 22.5 & 7 & 17.5 \\
\hline
\end{tabular}




\begin{tabular}{|l|l|l|l|l|l|l|l|l|}
\hline $\begin{array}{l}\text { Risks in terms of achievement of } \\
\text { objectives }\end{array}$ & 6 & 15.0 & 11 & 27.5 & 13 & 32.5 & 10 & 25.0 \\
\hline $\begin{array}{l}\text { The company also had ability to assess } \\
\text { risk in terms of potential impact }\end{array}$ & 18 & 45.0 & 9 & 22.5 & 4 & 10.0 & 9 & 22.5 \\
\hline $\begin{array}{l}\text { Company has ability to prioritize risks it } \\
\text { faces }\end{array}$ & 13 & 32.5 & 20.0 & 50.0 & 0 & 0 & 7.0 & 17.5 \\
\hline $\begin{array}{l}\text { Company carries out a comprehensive } \\
\text { and systematic identification of risk }\end{array}$ & 10.0 & 25.0 & 20.0 & 50.0 & 7.0 & 17.5 & 3.0 & 7.5 \\
\hline
\end{tabular}

Source: Primary data (2018)

Table 2 also shows that the company analyzed its risks in terms of reputation impact with $12(30.0 \%)$ strongly agree and the same number of the respondents also agree on the same.9)22.5\%) of the respondents were undecided and $7(17.5 \%)$ strongly disagree that company does not analyzed its risks in terms of reputation impact. The company analyzed its risks in terms of achievement of objectives majority of the respondents $13(32.5 \%)$ were undecided, $11(27.5 \%)$ agree, 10(25.0\%) strongly disagree and $6(15.0 \%)$ strongly agree.

The company also had ability to assess risk in terms of potential impact with most of the respondents having $18(45.0 \%)$ strongly agree, $9(22.5 \%)$ agree and the same number of the respondents also strongly disagree. Only $4(10.0 \%)$ were undecided whether the company also had ability to assess risk in terms of potential impact. Looking whether the company has ability to prioritize risks it faces, majority of the respondents $20(50.0 \%)$ agree, $13(32.5 \%)$ strongly agree and only $7(17.5 \%)$ strongly disagree that the company does not have ability to prioritize risks it faces.

\subsubsection{Impact of Risk Management}

Summarized below are results on the impact of risk management of several variables.

Table 3. Impact of risk management

\begin{tabular}{|l|l|l|l|l|l|l|l|l|l|}
\hline & \multicolumn{2}{|l|}{ Strongly Agree } & \multicolumn{2}{l|}{ Agree } & \multicolumn{2}{l|}{ Undecided } & \multicolumn{2}{l|}{ Strongly Disagree } \\
\hline & Fre & $\%$ & Fre & $\%$ & Fre & $\%$ & Fre & $\%$ \\
\hline $\begin{array}{l}\text { Carries out comprehensive } \\
\text { systematic identification of risk. }\end{array}$ & 10 & 25 & 20 & 50 & 7 & 17.5 & 3 & 7.5 \\
\hline sources of strategic risks & 18 & 45 & 12 & 30 & 7 & 17.5 & 3 & 7.5 \\
\hline $\begin{array}{l}\text { internal audit staff taking } \\
\text { measures to control risks }\end{array}$ & 16 & 40 & 15 & 37.5 & 6 & 15 & 3 & 7.5 \\
\hline $\begin{array}{l}\text { management key business risk } \\
\text { facing known by internal auditors }\end{array}$ & 13 & 32.5 & 19 & 47.5 & 8 & 20 & 0 & 0 \\
\hline
\end{tabular}

Source: Primary data (2018)

It is seen from table 2 that Rift Valley Bottlers Limited Company agreed 20(50.0\%) carried out a comprehensive and systematic identification of risks, $10(25.0 \%)$ strongly agreed, $7(17.5 \%)$ were undecided on whether the company carried out a comprehensive and systematic identification of risks or not while $3(7.5 \%)$ strongly disagreed.

On company considering sources of strategic risks when identifying risks, it is seen that $18(45.0 \%)$ of the employees strongly agreed, $12(30.0 \%)$ agreed, $7(17.5 \%)$ undecided and 3(7.5\%) strongly disagreed. Revealing that, the Company considered sources of strategic risks when identifying risks in the company.

The findings shows that $16(40.0 \%)$ of the employees strongly agreed that the company internal audit staff takes all necessary measures to control risks in auditing process, 15(37.5\%) agreed, 6(15\%) undecided while $3(7.5 \%)$ strongly disagreed revealing that coca cola company measures to control risks in auditing process. It is seen that management view of key business risk facing the company was known by internal auditors with $19(47.5 \%)$ agreeing to it, 13(32.5\%) strongly agreed while $8(20.0 \%)$ were undecided.

\subsubsection{Budget Control}

From the table below, the researcher wanted to find out the budget control among the employees in the company. 
Table 4. Budget Control

\begin{tabular}{|c|c|c|c|c|c|c|c|c|}
\hline & \multicolumn{2}{|c|}{$\begin{array}{l}\text { Strongly } \\
\text { Agree }\end{array}$} & \multicolumn{2}{|c|}{ Agree } & \multicolumn{2}{|c|}{ Undecided } & \multicolumn{2}{|c|}{$\begin{array}{l}\text { Strongly } \\
\text { Disagree }\end{array}$} \\
\hline & Fre & $\%$ & Fre & $\%$ & Fre & $\%$ & Fre & $\%$ \\
\hline budget covers all sectors & 13 & 32.5 & 7 & 17.5 & 14 & 35 & 6 & 15 \\
\hline planned funds not realized as expected & 13 & 32.5 & 7 & 17.5 & 14 & 35 & 6 & 15 \\
\hline diversion of funds & 16 & 40 & 14 & 35 & 10 & 25 & 0 & 0 \\
\hline spend funds beneficial to themselves & 18 & 45 & 13 & 32.5 & 2 & 5 & 7 & 17.5 \\
\hline over expenditures on some votes & 16 & 40 & 14 & 35 & 10 & 25 & 0 & 0 \\
\hline management monitors objectives & 2 & 5 & 8 & 15 & 10 & 25 & 20 & 50 \\
\hline
\end{tabular}

Source: Primary data (2018)

From table 4 it revealed that majority of the employees $14(35 \%)$ were undecided whether the company budget covers all sectors, $13(32.5 \%)$ of the respondents strongly agreed. $7(17.5 \%)$ of the employees agree that the company budget covers all sectors and the minority $6(15 \%)$ strongly disagree that the company does not cover all budget sectors.

On investigating whether the planned funds are not realized as expected, 14(35\%) of the respondent's undecided, $13(32.5 \%)$ strongly agreed, $7(17.5 \%)$ agreed and $6(15 \%)$ strongly disagree that planned funds are not realized as expected. Therefore, the results show that employees in the Rift Valley Bottlers Company are not sure whether the planned funds are realized as expected.

The Researcher also wanted to find out from the employees if diversion of funds occurs when the proposed amount of funds is not realized. From the results in table 4 above, it indicates that most of the employees 16(40\%) strongly agree, 14(35.5\%) agree and the other 10(25\%) were undecided whether diversion of funds occur when the proposed amount of funds is not realized.

Investigating on whether funds are spent as planned, majority of the employees 20(50\%) strongly disagreed, followed by $10(25 \%)$ undecided, $8(20 \%)$ agree and $2(5 \%)$ strongly agreed that funds are spent as planned. The result reveals that funds are not spending as planned.

Findings on whether management had a tendency to spend funds on items that are beneficial to themselves. $18(45 \%)$ strongly agreed, $13(32.5 \%)$ agreed, $7(17.5 \%)$ strongly disagreed and $2(5 \%)$ were undecided. The results therefore indicate that majority of the employees in Rift Valley Bottlers Company has a tendency to spend funds for their own benefits.

The study sought to find out whether there is some situation of over expenditure on some votes in the company, majority of the respondents $14(35 \%)$ agree $26(40 \%)$ strongly agreed and the other $10(25 \%)$ were undecided whether there are over expenditures on some votes in the company. Still from table 4 results shows that $20(50 \%)$ of the respondents strongly disagree that management do not monitor objectives against budget. 10(25\%) were undecided, 8(15\%) agree and 2(5\%) strongly agree. The results illustrate that the management of Rift Valley Bottlers Company do not monitor objectives against objective and budget.

\subsubsection{Financial Accountability}

The study sought to assess the financial accountability of rift valley bottlers and findings recorded in table 5.

Table 5. Financial Accountability

\begin{tabular}{|l|l|l|l|l|l|l|l|l|}
\hline & \multicolumn{2}{l}{ Strongly Agree } & \multicolumn{2}{l}{ Agree } & \multicolumn{2}{l|}{ Undecided } & \multicolumn{2}{l|}{$\begin{array}{l}\text { Strongly } \\
\text { Disagree }\end{array}$} \\
\cline { 2 - 9 } & Fre & \% & Fre & \% & Fre & \% & Fre & $\%$ \\
\hline $\begin{array}{l}\text { Financial transaction with co complete } \\
\text { and accurate record }\end{array}$ & 17 & 42.5 & 8 & 20 & 7 & 17.5 & 8 & 20 \\
\hline support of accounting procedures & 13 & 32.5 & 14 & 35 & 5 & 12.5 & 8 & 20 \\
\hline $\begin{array}{l}\text { stakeholders satisfied with company } \\
\text { expenditures }\end{array}$ & 16 & 40 & 13 & 32.5 & 11 & 27.5 & 0 & 0 \\
\hline $\begin{array}{l}\text { management produces balance sheets } \\
\text { periodically }\end{array}$ & 11 & 27.5 & 14 & 35 & 7 & 17.5 & 8 & 20 \\
\hline verify and validate internal audit & 20 & 50 & 14 & 35 & 4 & 10 & 0 & 0 \\
\hline audits carried out regularly & 11 & 27.5 & 11 & 27.5 & 7 & 17.5 & 11 & 27.5 \\
\hline tender bids reviewed & 12 & 30 & 7 & 17.5 & 12 & 30 & 9 & 22.5 \\
\hline accounts activities monitored & 7 & 17.5 & 16 & 37.5 & 13 & 32.5 & 4 & 10 \\
\hline slow accountability & 15 & 37.5 & 3 & 7.5 & 4 & 10 & 18 & 45 \\
\hline
\end{tabular}

Source: Primary data (2018) 
5.

The study assessed the financial accountability of rift valley bottlers results are summarized in table

From the findings it is seen that $17(42.7 \%)$ of the employees strongly agreed that every financial transaction at Rift Valley Bottlers transact with complete and accurate record, $8(20 \%)$ agree and the same number of the employees also strongly disagree. The remaining $7(17.5 \%)$ of the employees were undecided whether they transact with complete an accurate record.

The study sought to find out from the employees if they supported the accounting procedures used in Rift valley bottlers and revealed that 14(35\%) agreed that they supported the accounting procedure used, 19(32.5\%) strongly agreed, $8(20 \%)$ strongly disagreed while $5(12.5 \%)$ were undecided. From the results, it is revealed that employees of Rift valley bottlers strongly agreed to support the accounting procedure used.

Investigating whether all stakeholders are always satisfied with company expenditures, Majority of the respondents $16(40 \%)$ strongly agreed, followed by 13(32.5\%) agreed and 11(27.5\%) undecided whether all stakeholders are always satisfied with company expenditures.

It is seen that $14(35.0 \%)$ of the respondents agreed that management periodically produces balance sheet to show the organizations cash inflows and out flows. 11(27.5\%) strongly agreed, $8(20 \%)$ strongly disagreed and the remaining $7(17.5 \%)$ were undecided whether the management periodically prepare balance sheet. From the results obtained, it illustrates that employees in Rift valley Bottlers Company agreed that management periodically prepares balance sheet.

The researcher wanted also to find out whether the employees verify and validate the internal audit in their financial statement. It was found that most of the employees $20(50 \%)$ strongly agree that they validate and verify financial statements, $14(35 \%)$ agreed and the other 4(10\%) were undecided whether the employees verify and validate their financial statements.

To investigate on the value for money audits carried out regularly, most of the employees $11(27.5 \%)$ strongly agreed, agree and the same number of the employees strongly disagree. The minority of the employees $7(17.5 \%)$ of the employees were undecided whether value for money audits are done regularly or not.

On finding out if the employees tenders in company are reviewed with value of money. Majority of the respondents $12(30 \%)$ strongly agreed and the same number also was undecided. $9(22.5 \%)$ strongly disagree and the remaining $7(17.5 \%)$ agree that all tender bids in the company are reviewed with value for money.

From the study, it is indicated that $16(37.5 \%)$ of the respondents agreed that on accounts activities monitored, 13(32.5\%) were undecided, 7(17.5\%) strongly agreed and 4(10\%) strongly disagree. This reveals that majority of the respondents agreed that accounts activities are monitored and supervised to ensure value for money.

On finding out whether advances given accountability are slow, most of the employees $18(45 \%)$ strongly disagree, $15(37.5 \%)$ strongly agreed, $4(10 \%)$ were undecided and the remaining 3(7.5\%) agreed that advances give in accountability are very slow.

\subsubsection{Indicators of Financial Performance}

The study sought to determine the indicators of financial performance of Rift Valley Bottlers.

Table 6. Indicators of Financial Performance

\begin{tabular}{|l|l|r|r|r|r|r|}
\hline Statements & SA & A & U & \multicolumn{1}{l|}{ SD } & Total \\
\hline Enhance profit level & Frequency & 7 & 17 & 8 & 8 & 40 \\
\cline { 2 - 7 } & Percentage & 17.5 & 42.5 & 20 & 20 & 100 \\
\hline \multirow{2}{*}{ Increases the growth of shareholders wealth } & Frequency & 8 & 15 & 12 & 5 & 40 \\
\cline { 2 - 7 } & Percentage & 20 & 37.5 & 30 & 12.5 & 100 \\
\hline \multirow{2}{*}{ Enhance company expansion } & Frequency & 10 & 12 & 7 & 11 & 40 \\
\cline { 2 - 7 } & Percentage & 25 & 30 & 17.5 & 27.5 & 100 \\
\hline Reduce occurrence of liquidation & Frequency & 7 & 17 & 6 & 10 & 40 \\
\cline { 2 - 7 } & Percentage & 17.5 & 42.5 & 15 & 25 & 100 \\
\hline Minimizes financial errors & Frequency & 12 & 11 & 5 & 12 & 40 \\
\cline { 2 - 7 } & Percentage & 30 & 27.5 & 12.5 & 30 & 100 \\
\hline
\end{tabular}

Source: Primary data (2018)

From the findings $17.5 \%$ of the respondents strongly agreed, $42.5 \%$ agreed, $20 \%$ were undecided 
and $20 \%$ strongly disagreed that financial performance is measured in terms of profit value where the company is evaluated on the returns gained after sales of goods.

The results indicate $20 \%$ of the participants strongly agreed, $37.5 \%$ agreed, $30 \%$ were undecided and $12.5 \%$ strongly disagreed that the management makes sure the shareholder value is increased in terms of the share returns.

Table 6 shows $25 \%$ of the respondents strongly agreed, $30 \%$ agreed, $17.5 \%$ were undecided and $27.5 \%$ strongly disagreed that the financial management of Rift Valley Bottlers makes sure it reduces its operations cost in order to increase its financial growth through opening other branches in the country.

From the study $17.5 \%$ of the participants strongly agreed, $42.5 \%$ agreed, $15 \%$ were undecided and $25 \%$ strongly disagreed that the company makes sure its funds are used efficiently in order to reduce occurrence of liquidation.

Moreover, the results indicate $30 \%$ of respondents strongly agreed, $27.5 \%$ agreed, $12.5 \%$ were undecided and $30 \%$ strongly disagreed that using proper internal audit systems helps to minimize financial errors hence promoting financial accountability.

\subsection{Discussion of the Findings}

\subsubsection{Internal Audit Functions and Financial Performance}

From the findings, it reveals internal audit function affects financial performance of Rift Valley Bottlers where staff adhered to controls in place; companies have proper monitoring of internal control systems. record of assets is not maintained; accuracy of information is emphasized in their company; assets were kept in custody of authorized personnel; clear levels of approval and authorization in the company; the Company identifies risks in terms of sources; and Rift Valley Bottlers analyzed risks in terms of consequences.

Douglas et al. (2012) concur with the findings where he found that the issuance of an internal audit report (IAR) to external stakeholders affects internal auditors' judgments. Additionally, the results indicated that when the Chief Audit Executive reports primarily to the Audit Committee Chair, internal auditors' control risk assessments are higher.

The study is concurred where he found in order for a Board and management to achieve good governance an audit committee's role is to confirm internal audit's assurance that internal control systems exist; and financial reports are properly prepared in accordance with accounting principles and standards; and independently audited by professional external auditors.

\subsubsection{Risk Management and Financial Performance}

From the findings, majority of participants were of the opinion that risk management impacts financial performance whereby company does not analyzed its risks in terms of reputation impact; the company also had ability to assess risk in terms of potential impact; the company does not have ability to prioritize risks it faces;; a comprehensive and systematic identification of risks; the Company considered sources of strategic risks when identifying risks in the company; the company internal audit staff takes all necessary measures to control risks in auditing process; Rift Valley Bottlers company measures to control risks in auditing process; and management view of key business risk facing the company was known by internal auditors.

Cristina (2010) concur with the findings where he found out that proper internal audit system enhances good governance and accountability. Also, the results concur with Aaron and Gabriel (2010) findings where they found out that top management acts as a determinant of IA effectiveness.

\subsubsection{Budgetary Controls and Financial Performance}

Budgetary control is very important in an organization since it reduces the cost of operations and helps in managing of the firm finances. It was revealed the effects of budgetary control on financial performance at Rift Valley Bottlers were that the company budget covers all sectors and the minority; planned funds are not realized as expected; diversion of funds occur when the proposed amount of funds is not realized; funds are not spending as planned; Rift Valley Bottlers Company has a tendency to spend funds for their own benefits; and the management of Rift Valley Bottlers Company do not monitor objectives against objective and budget.

Ebrahim et al. (2014) concur with the findings where he found out that internal audit department is very important inside a firm where the internal audit is regarded as the key element in the application of accounting systems and this in turn, helps in evaluating the work of the department. The internal audit is considered as the backbone of the business accounting as it is the section that records all businesses 
related to the sector. The efficiency of internal audit helps develop the work of the company because the financial reports reflect the internal audit department's quality.

The findings are concurred by Sofil and Ngwenya (2014) where they found out that the causes of negative perceptions were agreed by $78 \%$ of respondents and some of the causes of negative perception were; auditors failure to meet expectation gap, bad reputation of an auditor, the quality of audit staff, level of professional competence and the absence of independence and objectivity in internal audits.

\subsubsection{Financial Accountability and Financial Performance}

Financial accountability at Rift Valley Bottlers enhances financial performance since every financial transaction at Rift Valley Bottlers transact with complete and accurate record; employees of Rift Valley bottlers support the accounting procedure used; all stakeholders are always satisfied with company expenditures; management periodically prepares balance sheet; employees verify and validate their financial statements; value for money audits are done regularly; all tender bids in the company are reviewed with value for money; accounts activities are monitored and supervised to ensure value for money; and advances give in accountability are very slow.

Ondieki (2013) concur with the findings that internal audit standards, independence of internal audit, professional competency and internal control had a positive relationship with financial performance of commercial banks.

The findings are concurred by Bett (2014) who found out that effective internal audit function has a positive influence on financial performance of companies listed at the NSE.

\subsection{Interpretation of the Findings}

From the results majority of the respondents with $48.6 \%$ (mean 2.43) were of the view that records of company assets are maintained in order to reduce occurrence of liquidation and also increase the value of the assets hence increasing Return on Assets (ROA).

From the findings majority of participants with 52.6\% (mean of 2.63) were of the opinion that identified risks are managed immediately in order to reduce low rate of returns and decrease of shareholder value in order to increase Return on Earnings (ROE).

From the results majority of the respondents with $52.6 \%$ (mean 2.63) agreed that advances are given and accountability is very slow since the company majors on important financial issues.

From the finding's majority of participants with $52.6 \%$ (mean of 2.63) were of the opinion that every financial transaction at this Company has complete and accurate records and every transaction made in the company follow the accounting and audit principles.

\subsection{Regression Analysis}

The study sought to investigate the relationship between independent and dependent variable using multiple liner regression.

Table 7. Model Summary representing the linear relationship between independent and dependent variables

\begin{tabular}{|l|r|r|r|r|}
\hline \multicolumn{6}{|c|}{ Model Summary } \\
\hline Model & R & R Square & Adjusted R Square & Std. Error of the Estimate \\
\hline 1 & $.984^{\mathrm{a}}$ & .969 & .965 & .20320 \\
\hline
\end{tabular}

a. Predictors: (Constant), Financial accountability, Internal audit function, Risk management, Budgetary control Source: Primary data (2018)

Table 7 above displays $\mathrm{R}$ (the correlation between the observed and predicted values of the dependent variable), which is $0.984^{\mathrm{a}}$. This is a very strong relationship between the observed and predicted values of the dependent variable.

The table also displays $\mathrm{R}$ squared which is the proportion of variation in the dependent variable explained by the regression model. In this case, it is 0.969 . This means that $96.9 \%$ of the variation on financial performance dependent variable can be explained from the three independent variables. The value of the standard error $(\mathrm{sy} / \mathrm{x})$ is shown in the output as 0.20320 .

The regression was a very good fit describing $96.5 \%$ of the variance in financial performance R2adj $=96.5 \%$ this indicates only a slight overestimate with the model. 
Table 8. An ANOVA representing the linear relationship between independent variables and financial performance

\begin{tabular}{|l|l|r|r|r|r|c|}
\hline \multicolumn{7}{|c|}{ ANOVA $^{\mathbf{a}}$} \\
\hline \multicolumn{2}{|c|}{ Model } & Sum of Squares & df & Mean Square & F & Sig. \\
\hline \multirow{2}{*}{1} & Regression & 45.049 & 4 & 11.262 & 272.769 & $.000^{\text {b }}$ \\
\cline { 2 - 8 } & Residual & 1.445 & 35 & .041 & & \\
\cline { 2 - 8 } & Total & 46.494 & 39 & & & \\
\hline
\end{tabular}

a. Dependent Variable: $\mathrm{f}$

b. Predictors: (Constant), Financial accountability, Internal audit function, Risk management, Budgetary control Source: Primary data (2018)

The overall relationship was statistically significant $(\mathrm{F}=272.769, \mathrm{p}=0.000)$. The study results indicated that the regression model was significant at $\mathrm{p}=0.000$.

Table 9. Coefficients representing the linear relationship between independent variables and staff turnover

\begin{tabular}{|c|c|c|c|c|c|c|}
\hline \multicolumn{7}{|c|}{ Coefficients $^{\mathrm{a}}$} \\
\hline \multirow{2}{*}{\multicolumn{2}{|c|}{ Model }} & \multicolumn{2}{|c|}{ Unstandardized Coefficients } & \multirow{2}{*}{$\begin{array}{c}\text { Standardized } \\
\text { Coefficients } \\
\text { Beta } \\
\end{array}$} & \multirow[t]{2}{*}{$\mathrm{T}$} & \multirow[t]{2}{*}{ Sig. } \\
\hline & & $\mathrm{B}$ & Std. Error & & & \\
\hline \multirow[t]{5}{*}{1} & (Constant) & -.372 & .152 & & -2.454 & .019 \\
\hline & Internal audit functions & .503 & .137 & .477 & 3.680 & .001 \\
\hline & Risk Management & .167 & .079 & .130 & 2.115 & .042 \\
\hline & Budgetary Control & .472 & .151 & .411 & 3.131 & .004 \\
\hline & Financial accountability & -.081 & .027 & -.095 & -3.017 & .005 \\
\hline
\end{tabular}

a. Dependent Variable: Financial Performance

Source: Primary data (2018)

The regression equation was modeled as follows: $Y=\beta_{0}+\beta_{1} X_{1}+\beta_{2} X_{2}+\beta_{3} X_{3}+\beta_{4} X_{4}+$ error (e)

The regression equation computed was:

$\mathrm{Y}=-0.372+0.477+0.130+0.411-0.095+0.152$

$Y($ Financial performance $)=-0.372+0.477($ internal audit functions $)+0.130($ risk management $)+$ 0.411 (budgetary control) -0.095 (financial accountability) +0.152 (Standard Error).

From the equation it is therefore clear that the internal audit functions affects financial performance of Rift Valley Bottlers up to $47.7 \%$ followed by budgetary control which affects financial performance in the company up to $41.1 \%$, also risk management affects financial performance of drink company up to $13 \%$ and lastly financial accountability which affects financial performance of Rift Valley Bottlers up to $9.5 \%$.

\subsubsection{Hypothesis Testing}

$\mathbf{H}_{01}$ : Internal audit function does not have a significant effect on financial performance of Rift Valley Bottlers Limited Eldoret.

The study findings indicated there was a significant relationship between financial performance of Rift valley Bottlers Limited ( $\mathrm{p}=0.001)$.

The study therefore rejects the null hypothesis.

This implies that the company makes sure that finances are used efficiently and effectively in order to reduce financial errors for accountability and transparency purposes. The findings are supported by Bett (2014) who found out that effective internal audit function has a positive influence on financial performance of companies listed at the NSE.

$\mathbf{H}_{\mathbf{0 2}}$ : $\quad$ Risk management does not have a significant effect on financial performance of Rift Valley Bottlers Limited Eldoret.

The study findings indicated there was a significant relationship between risk management and financial performance of Rift Valley Bottlers Limited Eldoret. $(\mathrm{p}=0.042)$.

The study therefore rejected the null hypothesis.

This implies that the company identifies risks early in order to reduce low rate of returns and decrease of shareholder value in order to increase Return of Earnings (ROE). The study is supported by Odoyo and Omwono (2014) where they found out that management of State Corporation needs to create an environment that will harness commitment and support to internal audit if it is to effectively perform its responsibility of giving assurance that organizational risks are managed effectively. 
$\mathbf{H}_{\mathbf{0 3}}$ : There is no significant relationship between budgetary control on financial performance of Rift Valley Bottlers Limited Eldoret.

The study findings indicated there was a significant relationship between budgetary control and financial performance of Rift Valley Bottlers Limited Eldoret ( $\mathrm{p}=0.004)$.

The study therefore rejected the null hypothesis.

This implies budget covers all sectors and the minority and planned funds are realized as expected in order to reduce misuse of funds.

Ebrahim et al. (2014) concur with the findings where he found out that internal audit is considered as the backbone of the business accounting as it is the section that records all businesses related to the sector. The efficiency of internal audit helps develop the work of the company because the financial reports reflect the internal audit department's quality.

$\mathbf{H}_{04}$ : Financial accountability does not have a significant effect on financial performance of Rift Valley Bottlers Limited Eldoret.

The study findings indicated there was a significant relationship between financial accountability and financial performance of Rift Valley Bottlers Limited Eldoret. $(\mathrm{p}=0.005)$.

The study therefore rejects the null hypothesis.

This implies that every financial transaction of Rift Valley Bottlers is accounted for in order to enhance accountability and transparency. Also, the accountants follow the audit principles and systems in order to enhance accuracy and reduce transaction errors.

The findings are supported by Ondieki (2012) where he found out that independence of internal audit, professional competency and internal control had a positive relationship with financial performance of commercial financial institutions.

\section{Findings}

\subsection{Summary of the Findings}

This study investigated effect of internal audit function on financial performance in Rift Valley bottlers limited Eldoret, Kenya. In summary, the following results were obtained, 20(50\%) of the respondents had bachelor's degree and the majority 34(85\%) were married in Rift valley bottlers limited.

In relation to proper monitoring of internal control systems in the company 16(40.0\%) of the respondents agreed that there was proper monitoring of internal control systems, Accuracy of information in any organization is very important in measuring internal control in an organization, the study sought to find out if accuracy of information was emphasized in the company. From the analysis it observed that majority $17(42.5 \%)$ of the employees agreed that accuracy of information is emphasized in their company .The discussion also showed that records of assets were not maintained with 19(47.5\%) of the respondents strongly disagreed, the findings also shows that 18(45.0\%) of the employees agreed that assets register is regularly updated. The study went further to find out if assets were kept in custody of authorized personnel with the majority of the respondents 19(47.5\%) agreed that assets were kept in custody of authorized personal. It is also seen that most of the employees $22(55.0 \%)$ strongly agreed that the company has measures to safeguard assets from fire, while the majority $23(57.5 \%)$ agreed that there were clear levels of approval and authorization in the Rift Valley Bottlers Limited Company.

Looking at the company identifying risks in terms of sources of risks, it was found that majority of employees 21(52.5\%) agreed that company identified risks in terms of sources of risk it also shows that the company has a risk communication strategy with 18(45.0\%) of the employees agreeing. On investigating if the company analyzed risks implying that Rift Valley Bottlers analyzed risks in terms of consequences. The results show that the company analyzed its risks in terms of reputation impact with $12(30.0 \%)$ strongly agree and the same number of the respondents also agreed on the same. The company analyzed its risks in terms of achievement of objectives majority of the respondents $13(32.5 \%)$, the company also had ability to assess risk in terms of potential impact with most of the respondents having $18(45.0 \%)$ strongly agree, that the company also had ability to assess risk in terms of potential impact. Investigations on whether the company had ability to prioritize risks it faced, majority of the respondents $20(50.0 \%)$ agreed that the company had the ability.

The results on comprehensive and systematic identification of risks indicated 20(50.0\%) of the respondents agreed that it was carried out at the company. In addition, 18 (45.0\%) of the respondents strongly agreed that, the Company considered sources of strategic risks when identifying risks in the company. The findings also showed that $16(40.0 \%)$ of the respondents strongly agreed that the company's internal audit staff took all necessary measures to control risks in auditing process. Management view of 
key business risk facing the company was known by internal auditors with 19(47.5\%) of the respondents agreeing to it.

The study assessed the financial accountability of Rift Valley Bottlers and the results summarized that $17(42.7 \%)$ of the respondents strongly agreed that every financial transaction had complete and accurate records. Results on employees support of accounting procedures used in Rift valley bottlers showed that majority 14(35\%) agreed. On investigating whether all stakeholders were satisfied with company expenditures, majority of the respondents 16(40\%) strongly agreed. Majority $14(35.0 \%)$ of the respondents agreed that management periodically prepared balance sheet that showed the organizations cash revenues and expenditures.

More findings showed that majority of the respondents 20(50\%) strongly agree that the company validates and verifies financial statements. On investigating whether value for money audits were carried out regularly, most of the employees $11(27.5 \%)$ strongly agreed. On finding out if tender bids in company were reviewed with concern of value of money, majority of the respondents $12(30 \%)$ strongly agreed and the same number were undecided. The study, showed that $16(37.5 \%)$ of the respondents agreed that accounts activities were monitored and supervised to ensure value for money. finding out whether advances given delays accountability, majority of the respondents $18(45 \%)$ strongly disagree.

Looking at budget performance, the results illustrated that majority of the respondents $14(35 \%)$ were undecided and on whether the company budget covered all sectors majority $13(32.5 \%)$ strongly agreed. On whether the planned funds were not realized as expected, 14(35\%) of the respondents were undecided. Results indicated that most respondents $16(40 \%)$ strongly agree diversion of funds occurred when the proposed amount of funds was not realized. Whether funds were spent as planned, majority of the employees $20(50 \%)$ strongly disagreed. On analyzing whether management had a tendency to spend funds on items that were beneficial to themselves, 18(45\%) strongly agreed. Majority of the respondents $14(35 \%)$ agreed that over expenditure on some votes in the company occurred. Also 20(50\%) strongly disagree that management do not monitor objectives against budget.

There was a relationship between internal audit function on financial performance of Rift valley bottlers. Therefore, in order to improve on financial performance, there is need to develop an internal control function plan. Murrill and Murrill (2003) also found out that there is strong positive relationship between internal audit function on financial performance. The correlations above between Risk management on financial performance showed a relationship between the risk management variables and financial performance with their $\mathrm{p}$ values less than $0.05(\mathrm{p}<0.05)$. The results concur with several other studies which draw the link between good risk management practices with improved financial performances (Aaron and Gabriel, 2010; Cristina, 2010). In particular, these studies propose that prudent risk management practices reduce the volatility in banks' financial performance, namely operating income, earnings, firm's market value, share return and return on equity. (Aaron and Gabriel (2010)) proposed that ensuring best practices through prudent risk management result in increased earnings.

\subsection{Conclusions}

The purpose of this study was to investigate effect of internal audit function on financial performance of Rift Valley Bottler's Limited, Eldoret. Internal auditing is an independent, objective assurance and consulting activity designed to add value and improve an organization's operations. It helps an organization meet its objectives by bringing a systematic, disciplined approach to evaluate and improve the effectiveness of risk management, control, and governance process. The institute of Internal Auditors is a recognized professional body with a bi-monthly internal auditing magazine, a certification program to Certified Internal Auditor (CIA) and many seminars and training opportunities, as well as its own research foundation with research on the history, developments and future of internal auditing. The early Statement of Responsibilities of Internal Audit (1947) described internal audit as an independent appraisal activity within an organization for the review on the accounting, financial and other operations as a basis for protective and constructive service to management. It is a type of control that functions by measuring and evaluating the effectiveness of other types of control. It deals primarily with accounting and financial matters, but it may also properly deal with matters of an operating nature. The study also found out that there is a significant relationship between internal audit function on financial performance of organizations. 


\subsection{Recommendations}

Basing on the study findings researcher recommends the following;

i. The study recommends organizations like Rift Valley Bottlers to always embrace and practice internal audit in order to improve their financial performance.

ii. The study further recommends that organizations should always conceive and adhere to the internal audit function in a positive way as it was communicated by employees and follow the standards set in the day to day running of the organization activities.

iii. This study further recommends training of employees in Rift Valley Bottlers as important motivational tool to employees towards better performance.

\subsection{Recommendations for further Research}

This study recommends that further research should be done on effect of internal audit function on financial performance in Rift Valley Bottlers' Limited Eldoret, Kenya to ascertain more information for future reference. Since the study used only questionnaires as a data collection tool, same study should be done by triangulation.

\section{References}

Aaron, C. and Gabriel, S. (2010). Effectiveness of internal Auditing. Australian Accounting Review, 20(3): 296-307.

Adams, M. B. (1994). Agency theory and internal Audit. Managerial Auditing Journal, 9(8): 8.

Bett, C. C. (2014). Effectiveness of Internal Audit functions and financial performance of companies listed on NSE. Unpublished Master's Thesis, university of Nairobi.

Cristina, S. (2010). Measuring the effectiveness of Internal Audit functions from an International point of view. 10: 137-46.

Daft, R. L. (2012). Management, ninth edition. South-Western, Cengage Learning.

Douglas, E. Z., Shu, L. and Mina, P. (2012). The Impact of Internal Audit Function Quality and Contribution on Audit Delays 52. Unpublished journal from College of Business and Public Administration Old Dominion University Norfolk, VA 23529 Electronic copy Available at: http://ssrn.com/abstract=1673490.

Ebrahim, M. A., Abdullah, A. and Faudziah, H. B. F. (2014). Effect of internal audit and firm performance in Malaysia. International Review of Management and Marketing, 4(1): 34-41.

Ejoh, N. O. (2014). Effect of Internal Audit functions on financial performance of Tertiary Institutions in Nigeria. International Journal of Economics, Commerce and Management, 2(10):

Flesher, D. L. (1996). Internal Auditing Standards and Practices (Altamonte Springs, FL; The Institute of Internal Auditors 1996).

Gupta, P. P. and Ray, M. R. (1992). The changing roles of the internal auditor. Managerial Auditing Journal, 7(1):

Kiema, H. M. (2015). Influence of internal audit independence on the financial performance of small and medium enterprises in construction industry in Mombasa County, Kenya. Unpublished Project, Technical University of Mombasa.

Muhunyo, B. M. and Jagongo, A. O. (2018). Effect of internal control systems on financial performance of public institutions of higher learning in Nairobi City County, Kenya. International Academic Journal of Human Resource and Business Administration, 3(2): 273-87.

Murrill, C. and Murrill, E. (2003). Reliance of external auditors on internal audit work, a review of qualitative finance and audit.

Odoyo, F. and Omwono, G. (2014). The role of internal audit in enhancing corporate governance for companies listed at the Nairobi stock exchange. Research Journal of Finance \& Accounting:

Ondieki, N. M. (2012). Effect of internal audit on financial performance of commercial banks in Kenya. Unpublished Project, University of Nairobi.

Ondieki, N. M. (2013). Effect of internal audit on financial performance of commercial banks in Kenya. Unpublished Project, University of Nairobi.

Rittenberg, L. E. and Covaleski, M. (2005). The outsourcing Dilemma: What is best for internal Auditing (Altamonte Springs, FL: The institute of Internal Auditors Research foundation.

Sawyer, L. B. and Dittenhofer, M. A. (1996). Internal Auditing, 4h ed. (Altamonte Springs. FL: The Institute of Internal Auditors. California State University, Fresno-Craig School of Business. 
Sofil, O. and Ngwenya, M. (2014). Internal Audit Perception and its Impact on performance of the Internal Audit function in Zimbabwe. IOSR Journal of Business and Management (IOSR-JBM), 16(5): $81-85$.

Volosin, E. (2007). The theories of audit expectations and the expectation gap. Munich, GRIN Publishing $\mathrm{GmbH}$. 